\title{
PASTORAL COUNSELLING IN A CHANGING SAMOA: DEVELOPMENT, CHRISTIANITY AND RELATIONALITY
}

\begin{abstract}
Alesana Pala'amo ${ }^{1}$
ABSTRACT

In Samoa, development and Christianity are pervasive and dynamic features of social life, and they are also entangled together in complex ways. This article reviews these entanglements by examining counselling as a form of pastoral practice. Counselling involves interventions that seek to facilitate, amend and restore people's relationships. The purpose of counselling in Samoa is to provide assistance in navigating the relational space between people, or vā, in the context of ongoing dynamic change. Counselling is a useful point of entry into research on development and Christianity because both have relational effects; they are experienced in and through relationships and relational reconfigurations. Drawing on my research into counselling services by Samoan ministers and their wives, I argue that faith-based counselling should be seen as potentially significant actor in the provision of counselling services on into the future.
\end{abstract}

Keywords: Christianity; development; Samoa; Pacific; counselling; relationality; $v \bar{a}$

\section{INTRODUCTION}

Since its introduction to Samoa from the 1820 , Christianity has come to be regarded by many Samoans as foundational to, indistinguishable from, and indeed practically synonymous with fa'aSamoa, or the Samoan way of life. Christianity is so enmeshed within everyday Samoan lifeworlds that it is impossible to properly understand Samoan economic practices, political processes and social phenomena without reference to religion. It is also the case that Christianity is deeply embedded in the imaginations, practices and discourses of Samoan development. This entanglement is so thorough that, arguably, to engage in serious research into Samoan development it is necessary to become a student of Samoan Christianity. It is also the case that, today, to engage in serious re- 
search on Samoan Christianity it is necessary to become a student of Samoan development. This is because each development project and intervention that aspires to reshape Samoan livelihoods is also necessarily an intervention into everyday Samoan religion.

The observation that development and Christianity are thoroughly interwoven has, in the past, not generally been a primary starting point for studies of Samoan development. This neglect can be read as a failure to adequately understand the pervasive, prominent and dynamic place of Christianity within fa'aSamoa. In this article, I examine the entanglements of Christianity and development in Samoa by focusing on counselling. At first glance, a focus on counselling may seem misplaced within a discussion about development. However, I suggest that counselling provides a valuable and productive lens through which to view the interactions between development and religion. This is because, at heart, counselling is a form of intervention which seeks to facilitate, amend and encourage relationships, and both Christianity and development in Samoa have deeply relational dimensions. In the attempt to help address tensions and relational disruptions, counselling is invested with issues that are of deep relevance to both Christianity and development.

My observations about Christianity and development in this article build upon my research into the changing roles of ministers within Samoan society and their potential growing involvement in the delivery of professional pastoral counselling services. ${ }^{2}$ My interest is more than merely academic; I am an ordained minister in the Ekalesia Faapotopotoga Kerisiano Samoa (Congregational Christian Church of Samoa; EFKs) and I regularly teach about the theology and practice of counselling at Malua Theological College. Moreover, with my wife Lemau, we have founded Soul Talk Samoa, an agency that provides counselling and social services. My involvement in the issues I address in this paper is therefore multi-located and multi-dimensional. Such entanglements, of course, are not dissimilar to those I am seeking to describe.

\section{SAMOAN CHRISTIANITY}

While it is correct to note that Christianity is pervasive within everyday Samoan life, it would be a mistake to extrapolate from this fact the idea that Christianity is singular or undifferentiated. In fact, there are many different churches in Samoa today, and they are marked by considerable differences in their theology, ecclesiology, rituals, leadership structures, ethical norms and practice. My research focuses on the EFKs, the church of which I am a member, and although I argue that the ideas I present in this paper are relevant to other churches in 
Samoa, and indeed to other churches around the Pacific, I also think there is value in attending to the specificity of this particular case study. The EFKS has a long history in Samoa, and a brief précis of this history will help set the background for my argument that follows.

Christianity arrived in Samoa during the first half of the nineteenth century. It was brought to Samoa by Polynesian travellers and converts, along with ship captains and crew, beachcombers, and European missionaries (Robson 2009, 22-24). John Williams, who served with the London Missionary Society (LMS), holds a particularly honoured status as the first European missionary to Samoa. He arrived in Samoa in 1830, via Tonga, together with a team of Tahitian and Cook Island teachers (Meleisea and Schoeffel-Meleisea 1987) - Tahiti and Rarotonga having been the sites of the LMs's first mission stations in the Pacific. Guided by Faueã and Puaseisei, a Samoan chief and his wife, the LMs missionaries were instructed to establish a mission station at Sapapali'i in Savai'i and it was here that they first proclaimed the Gospel on Samoan soil (Tofaeono 2000).

Of course, Samoans at that time were not devoid of spiritual or religious practices. Indeed, they already had a sophisticated indigenous religion which involved the worship of many different gods, ancestral spirits and ghosts (aitu), who were seen as being able to intervene in human affairs with both good and evil effects (Tofaeono 2000). Among the deities that Samoan people acknowledged was a creator god called Tagaloa-lagi who was responsible for creating all living things on earth (Tui Atua 2014). The early missionaries viewed the aitu as competitors with the Christian God, and much early missionary work was invested in seeking to discredit their authority or mana (Meleisea and Schoeffel-Meleisea 1987). As Christianity was increasingly adopted by Samoans, the reverence previously given to aitu was reassigned to the Christian God (Liuaana 2004). Great respect was also accorded to God's representatives: the foreign missionaries and the Samoan church ministers who replaced them. As this suggests, an overly sharp distinction between 'the days of darkness' (aso $o$ le pouliuli) and the 'the days of the good news' (aso ole tala lelei) is misleading, as this tends to erase the complicated cultural continuities that continue to shape Samoa today (Macpherson and Macpherson 2009, 106).

The LMs mission led to the establishment of the Samoan Church which was referred to simply as the LMS (Lā-Mō-Sā). It became, with the Methodist and Roman Catholic Churches, one of three pillars of what are now known as the 'traditional mainline churches' in Samoa. In 1962, the same year that Samoa achieved political independence from New Zealand, the LMS also gained independence from its parent body in the United Kingdom (Liuaana 2004). 
At this time, the Church also changed its name to Ekalesia Fa'apotopotoga Kerisiano Samoa (EFKS; also known as the Congregational Christian Church Samoa, or CCCs), and it became governed entirely by Samoan leadership. The shared timing of the two independence movements - ecclesial and national was not a coincidence. Both church and political movements shared much in common, including ideologies of liberation, determined leadership, and a sense that divine providence was moving the future forward in a clear and compelling direction. Samoa today remains a Christian nation - indeed, this status is enshrined in its Constitution ${ }^{3}$ - just as EFKs remains an independent church.

The pervasiveness of Christianity in Samoa is apparent in available statistics: the overwhelming majority of Samoans today affiliate with Christianity, with perhaps ninety-eight per cent identifying as Christian. ${ }^{4}$ For Cluny Macpherson and La'avasa Macpherson $(2009,106)$ 'Christianity was so completely embraced in Samoa that it is now seen to be a central institution, and indeed a pillar, of village life, and few if any people routinely think of it as an imported ideology'. For Melani Anae $(1998,87)$, Christianity and 'tradition' across the Pacific are frequently 'indistinguishable'. EFKs is one of the largest Churches with 31.8 per cent of the total population aged five years and older affiliating with the denomination. The importance of Christianity in Samoa, however, is not adequately understood at the aggregated level of statistics, but rather within lived experience. Churches have played vital roles within everyday village life, and this is not only in relation to religious belief. At least as transformative as their theologies were missionary attempts to impart literacy, books and new conceptions of education and health. Christianity also served as a major conduit for new ideas about law, politics, gender, kinship, work and materiality. It enabled new transnational networks and articulated new forms of belonging. Samoans were active in negotiating how these Christian ideas, technologies, organisational patterns and identities were received and embraced. Notwithstanding the continuities noted above, these collaborations had far-reaching consequences for the shape of Samoan society.

Although the terminology of 'development' was certainly an innovation of the second half of the twentieth century, as a process of cultural, social and economic transformation, development began much earlier. The arrival of Christianity had already effected far-reaching changes, and many Samoans continue to see development as a Christian concept, imbued with a religious aura on account of its association with Christianity. It can be argued that in Samoa development has often acquired a distinctly Christian hue. It is not, therefore, that development and Christianity have become increasingly entangled with each other over recent decades, but rather that the two concepts are intertwined. 
To point out these deep connections between Christianity and development is not to suggest that the two are entirely the same. This becomes clear when it is pointed out that the flows between Christianity and development have not moved only in one direction. If development has been influenced by Christianity, then Christianity has also been reconfigured by development. This is evident in the way that many of the moral challenges seen to be facing both Christianity and fa'aSamoa today are associated with development - for example, through economic growth, urbanisation, international migration and education. As a dynamic process for ongoing change, development continually reconfigures social relationships, providing ever new challenges for existing authorities, including both village leaders and title-holders (matai), and church ministers. ${ }^{5}$

\section{$V \bar{A} /$ RELATIONALiTY}

One important transformation emerging from development processes is what I call a 'changing Samoan self'. This involves change in ideas about who people are, and it emerges from transformations in identities and relationalities as Samoans come to conceive of themselves in new ways (Pala'amo 2017). This changing sense of what it is to be Samoan has been deeply shaped by development, and it is at the centre of new challenges facing communities in Samoa. I argue that this changing conception of the self requires new responses and reconfigured institutions. Among the new practices now required is a more effective and intentional system of counselling, with a widespread network of care capable of reaching all levels of society. Churches are well placed to provide this service; indeed, the fact that churches have at their disposal expansive networks and professionally trained ministers, and that they function as one of the primary social institutions of community life, makes them better located than any other organisation in Samoa to play this valuable role.

To understand what I mean by a 'changing Samoan self' it is necessary to consider the Samoan concept of $v \bar{a} .^{6} V \bar{a}$ refers to the relational space between people; it concerns the webs of relationships that connect or separate people from each other (Tuagalu 2008; Van der Ryn 2016). The importance of $v \bar{a}$ for Samoans is defined by Samoan poet and scholar Maualaivao Albert Wendt $(1999,402)$ :

Important to the Samoan view of reality is the concept of $V \bar{a}$ or Wa in Maori and Japanese. $V \bar{a}$ is the space between, the betweenness, not empty space, not space that separates, but space that relates, that holds separate entities and things together in the Unity-that-is-All, the space that is context, giving meaning to things. The meanings 
change as the relationships and the contexts change.... A well-known Samoan expression is 'Ia teu le $v \vec{a}$ ' - cherish, nurse, care for the $v \vec{a}$ ', the relationship. This is crucial in communal cultures that value group unity more than individualism, that perceive the individual person, or creature, or thing in terms of group, in terms of $v \bar{a}$, relationships.

As Wendt notes, Samoans are deeply concerned with the $v \bar{a}$ of their communities, and they seek to actively engage in its proper observance through careful management. To do so effectively involves an intentional cultivation and a 'looking after' the moral, ethical and spiritual dimensions of relationships (Anae 2010; 2016). As this suggests, concepts of $v \bar{a}$ involve an acknowledgement of the sacred or tapu nature of family and village relationality (Autagavaia 2001; Tamasese et al. 2005).

$V \bar{a}$ is more than rapport or perceived warmth in relationships. It also concerns forms of engagement which are considered proper and appropriate. For $v \bar{a}$ to be maintained requires the conduct ( $a g a)$ of certain forms of discipline, obedience and especially respect (fa'aaloalo) within the cluster of relational hierarchies - including both age and kinship - that structure Samoan communal life (Autagavaia 2001; Mulitalo-Lautā 2000). In this sense, $v \bar{a}$ is socially determined. So, for example, the observance of $v \bar{a}$ normally carries expectations that members of younger generations should respect those who are older, and this respect should be performed through bodily comportment and language. ${ }^{7}$ While this can be superseded in certain cases by other forms of hierarchy, the general rule is widely adhered to across Samoa. The most important locus for the learning and performance of these relational norms is in the family (aiga). When $v \bar{a}$ has been breached, it is frequently considered the duty of senior family members to discipline others in order to restore the appropriate relationships.

While $v \bar{a}$ can also encompass the relationality of people with other material and non-material objects, in this article I focus on inter-personal, and especially familial, relationships as this is the primary focus for counselling and a prominent focus in my research. The task of counselling in a Samoan context is, I argue, to acknowledge the relational space between people by assisting others in navigating their relationships, or fetu'utu'una'i le vā. A successful outcome from counselling is an enhanced capacity for such navigation. The practice of counselling should also be one in which $v \bar{a}$ is enhanced and, in this sense, $v \bar{a}$ is both the method and the ends of counselling in the Samoan context. Proper navigation of $v \bar{a}$ has the potential to encourage engagement, stimulate discussion and facilitate greater relational belonging. 
During my field research in Samoa I carried out extensive interviews about the value, purpose and changing roles of church-based counselling services. These interviews covered a broad range of topics, including diagnoses of social ills and inquiries into the possibilities of counselling to re-engender positive relationships. These interviews provided insights into the ways in which at least some Samoans perceive development as reconfiguring $v \bar{a}$ among their communities. Many of my research participants felt strongly that family, community and congregational relationships were undergoing substantial changes. Much of the commentary provided to me was of a negative nature, with the pointed suggestion that growing opportunities for development were coming at the cost to relationships fostered within fa'aSamoa and Christianity. It is tempting to see these perceptions as merely reactionary or traditionalist, and to dismiss them accordingly. However, I counsel against a flippant disregard for these views. Instead, I suggest that the perspectives of church leaders and others should be read as indicating deep concern with how to cultivate positive, culturally-appropriate and empowering $v \bar{a}$ within times of dynamic change. This concern with the integrity and vibrancy of relationships is also an indication of a desire to see the holistic well-being of their communities.

Numerous interviews highlighted that, as a consequence of significant economic growth over the past few decades, Samoans have new avenues to seek prosperity that were, in previous generations, unimaginable. This prosperity has led to new opportunities, as well as new challenges. Many of my informants associated prosperity with education and migration as strategies of economic advancement. These three ideas operated as an interconnected nexus, which can be seen as a synonym for 'development'. While all three ideas - prosperity, education and migration - were acknowledged as good and celebrated as such, they were also seen as creating new relational challenges for Samoan communities that needed to be addressed. ${ }^{8}$

Much concern over changing relationalities was focused on the extended family. Traditional family life in Samoan villages was based on multi-generational kinship networks that shared a proximate geography as well as a matai (elder or leader) who was endowed with considerable familial authority (Macpherson 1999). Each nuclear family was therefore located within a broader web of family connections. In such a context, close intergenerational relationships were very much a feature of everyday life, ensuring the imparting of advice to younger members as well as the care of aging members of the family (Tamasese, Parsons, and Waldegrave 2014). Changes in working patterns and employment opportu- 
nities, as well as interisland and international migration, have meant that this arrangement has come under new stresses and is no longer the assumed form of structuring family life. Instead, families are increasingly occupying their own separate houses based on smaller aiga units. Reverend Teuteronome, for example, drew clear links between development - which, as part of a common Samoan practice, he referenced through an association with palagi or Western ways of living - and reconfigurations to family relationships:

In terms of the leadership of [the family], there is a vast difference between a Samoan and a palagi family regarding the family unit. [A palagi family] includes only the couple and their children; they have a flat that houses their household and that's all they are concerned of. But here with the Samoan family, if the matai lives here, other households are located around him who serve and care for [the matai] and listen to the matai. [...] When you say that someone does not re-visit their family or village, he or she has become palagi [chuckles]. It means that the person does not want to be associated with his or her family anymore.

While this transformation from Samoan to palagi was treated as a matter for humour, it was also of deep moral concern. Migration, education or newfound prosperity were reconfiguring the possibilities of familial relationships.

As is also implied in the quote from Reverend Teuteronome, the changes in spatial family formations had their counterparts in changes in time. Reverend Numera, for example, talked with me about how the longer hours at work and school were reducing the time families spent with each other. This reduction in time spent together was adversely affecting the warmth and connectedness of families. As lives became busier, $v \bar{a}$ no longer received the care and attention that it required.

Both spatial and temporal changes were perceived by many of my informants as significantly impacting the quality of family life, which in turn also affected religious practice. The combination of religion and family was located particularly within the ritual practice of evening household devotions. A traditional practice for many Samoan households, family devotions took place at sunset and marked a time for households to gather together to worship and reflect on the day that had just ended. This was quiet time for families and, therefore, also for communities. Following the devotion was a time for informal and open discussions about any issues that needed addressing. The ritual elements and the relational elements of the evening devotions are, therefore, deeply 
connected. With changing spatial and temporal dynamics emerging out of development, this practice was seen by many of my informants as diminishing in value. One of my informants, Aitaua, expressed it in this way: 'Back in the day, evening devotions were a common practice in families .... Now I rarely hear of this practice anywhere. She lamented this decline for what it meant for both religious practice and familial relationships.

\section{CONCLUSION}

In this article I have argued that development and Christianity in Samoa are intimately connected with each other, both via historical associations as well as through contemporary dynamic interaction. My research into counselling in Samoa focuses on relational dimensions, and this relational field of inquiry has proven to be a valuable site of analysis for the development-religion encounter. This is because both development and Christianity have relational effects; both are experienced in and through relationships and relational reconfigurations.

My project is not, however, purely descriptive. Instead, I am interested in creating new ways to help Samoans navigate through the relational challenges that are now before them; to cultivate $v \bar{a}$ which is so central to Samoan notions of well-being. My primary concern is with the roles that the Samoan church may play within this. As a series of institutions which are pervasive and deeply embedded in Samoan communities, I argue that the church should be seen as a potentially significant actor in the provision of counselling services, and that such services are becoming increasingly important within Samoa today. While this proposal clearly has theological dimensions, I am especially interested in the possibilities of pastoral counselling as a form of community engagement and social practice. A movement for professional, culturally-sensitive, faith-based pastoral counselling would instigate further reconfigurations in the relationships between Christianity and development in Samoa. This is obviously not something that I think should be averted or fretted over. Such concerns could only be premised on a mythical notion of the prior separation of Christianity and development. As I have shown in this article, this is quite clearly not the case.

\section{ACKNOWLEDGEMENTS}

This paper was developed out of the author's doctoral research in the School of Social Work at Massey University New Zealand under the supervision of Professor Mark Henrickson, Dr Catherine Cook, and Dr Lily George. The research was supported through a scholarship by the Ekalesia Fa'apotopotoga Kerisiano 
Samoa (EFKS), as part of its staff development programme for Malua Theological College. Additional funding was secured through the Massey University Pasifika Doctoral Scholarships $(2015,2016)$, the Massey University School of Social Work Graduate Research Fund Trust, and the Norman Kirk Memorial Trust scholarship awarded by the Pacific Islands Polynesian Education Foundation. I am grateful for all the support which made my research possible.

\section{NOTES}

1 Alesana Pala'amo is the Head of Department of Practical Theology and lecturer at Malua Theological College in Samoa. He completed his PhD in Social Work in 2017 through Massey University in New Zealand. Alesana is also a minister in the Ekalesia Fa'apotopotoga Kerisiano Samoa (EFKs) Church and is the co-founder of Soul Talk Samoa.

Email: alesanapalaamo@yahoo.com.au

2 Research for this paper was carried out initially during the author's doctoral research (Pala'amo 2017). Interviews were conducted with participants living in Samoa and carried out predominantly in Samoan. The translations are my own. In accordance with ethics requirements, all identifiable material from the transcript segments presented has been omitted and pseudonyms have been assigned to each informant. My research was concerned with the counselling work of church ministers (faifeau), a role held by men, and their wives (faletua). Collectively, and often in close partnership, church ministers and their spouses play prominent roles within villages across Samoa in providing counselling, guidance, mediation and support to members of their communities.

3 The Preamble to the 2017 Constitution includes: 'Samoa is a Christian nation founded on God the Father, the Son and the Holy Spirit'.

4 The statistics cited here are from the Samoa Bureau of Statistics (2012). In addition to membership within Samoa, EFks has also expanded to other parts of the world including to New Zealand, Australia, the United States (including Hawaii and American Samoa) and Fiji. It is important to also note that there have been some significant decreases in membership in recent years.

5 In keeping with longstanding practices, matai titles can be bestowed upon both men and women, as too are land entitlements (Le Tagaloa 1986; Sua'ali'i 2001). Missionary Christianity instituted significant changes to traditional gender relationships, with women assuming increasingly domestic roles (Latai 2015; Taule'ale'ausumai 1997). Although women today continue to play important 
roles within parishes, their roles are frequently seen as subsidiary to those of their husbands (Siers and Ah Siu-Maliko 2003).

6 Concepts of $v \bar{a}$ share close similarities with parallel concepts in other indigenous Pacific cultures. The concept of tauhi va in Tonga also refers to the maintenance of space or relationships between two or more parties (Vakauta 2015). Durie (2007) has argued that, for Māori, the relational space between generations and genders, and with the ancestors, all demand particular respect and that this also should shape counselling practices. The Māori emphasis on kaupapa (principles) and tikanga (norms of right and proper conduct) are both connected with cultivating particular kinds of relational space (Shore 1989; Tate 2010).

7 The language of a young adult when they address a social senior, therefore, will normally be quite different from the language young adults will use with each other. Conversely, Samoan leaders are also expected to use different language sets depending on context in order to perform politeness and respect (Shore 2014).

8 See Macpherson, Bedford, and Spoonley's (2000) discussion of migration and education on labour market participation. Spoonley (2001) notes that international migration, including especially to New Zealand, has generated new sources of wealth that have impacted both the migrants and those who remained in Samoa. On migration, see especially Sailiemanu Lilomaiava-Doktor's (2015) study of Samoan journeyings (malaga), in which she frames Samoan migrations as involving interconnected links between social, spiritual, political and economic domains. As Lilomaiava-Doktor makes clear, Samoan values and practices have travelled along the journeyings, and this includes also their religious faith (Anae 1998; Tiatia 1998).

\section{REFERENCES}

Anae, Melani. 1998. 'Fofoa-i-vao-'ese: The Identity Journeys of NZ-Born Samoans'. $\mathrm{PhD}$ thesis, University of Auckland.

- 2010. 'Teu Le Va: Toward a Native Anthropology'. Pacific Studies 33 (2):222240.

- 2016. 'Teu Le Va: Samoan Relational Ethics'. Knowledge Cultures 4 (3):117130.

Autagavaia, Mary Kalala. 2001. 'Social Work with Pacific Island Communities'. In New Zealand Social Work: Contexts and Practice, edited by Marie Connolly, 
72-84. Melbourne, Australia: Oxford University Press.

Durie, Mason. 2007. 'Counseling Māori: Marae Encounters as a Basis for Understanding and Building Relationships'. New Zealand Journal of Counselling $27(1): 1-8$.

Latai, Latu. 2015. 'Changing Covenants in Samoa? From Brothers and Sisters to Husbands and Wives?' Oceania 85(1): 92-104.

Le Tagaloa, Aiono Fanaafi. 1986. 'Western Samoa: The Sacred Covenant'. In Land Rights of Pacific Women, 103-110. Suva: Institute of Pacific Studies of the University of the South Pacific.

Lilomaiava-Doktor, Sailiemanu. 2015. 'Journeyings: Samoan Understandings of Movement'. In Oceanian Journeys and Sojourns: Home Thoughts Abroad, edited by Judith A. Bennett, 66-92. Dunedin: Otago University Press.

Liuaana, Featunai Ben. 2004. Samoa Tula'i: Ecclesiastical and Political Face of Samoa's Independence, 1900-1962. Apia: Malua Printing Press.

Macpherson, Cluny. 1999. 'Changing Contours of Kinship: The Impacts of Social and Economic Development on Kinship Organization in the South Pacific'. Pacific Studies 22 (2): 71-95.

Macpherson, Cluny, Richard Bedford, and Paul Spoonley. 20oo. 'Fact or Fable? The Consequences of Migration for Educational Achievement and Labor Market Participation' The Contemporary Pacific 12 (1):57-82.

Macpherson, Cluny, and La'avasa Macpherson. 2009. The Warm Winds of Change: Globalisation in Contemporary Samoa. Auckland: Auckland University Press.

Meleisea, Malama, and Penelope Schoeffel-Meleisea. 1987. Lagaga: A Short History of Western Samoa. Suva: Institute of Pacific Studies, University of South Pacific.

Mulitalo-Lautā, Pa'u Tafaogalupe. 20oo. Fa'asamoa and Social Work: Within the New Zealand Context. Palmerston North: Dunmore Press.

Pala’amo, Alesana. 2017. 'Fetu’utu'una’i le vā, Navigating Relational Space: An Exploration of Traditional and Contemporary Pastoral Counselling Practices for Samoans'. PhD thesis, Massey University, Albany. 
Robson, Andrew E. 2009. 'Malietoa, Williams and Samoa's Embrace of Christianity', Journal of Pacific History 44 (1):21-39.

Samoa Bureau of Statistics. 2012. Population and housing Census 2011 Analytical Report. Apia: Samoa Bureau of Statistics.

Shore, Bradd. 1989. 'Mana and Tapu'. In Developments in Polynesian Ethnology, edited by Alan Howard and Robert Borofsky, 137-173. Honolulu: University of Hawai'i Press.

- 2014. 'A View from the Islands: Spatial Cognition in the Western Pacific'. Ethos 42(3):376-397.

Siers, Maureen, and Merci Ah Siu-Maliko. 2003.'Samoan Women and Theological Education'. In Samoan Women: Widening Choices, edited by Peggy FairbairnDunlop, 125-136. Suva: Institute of Pacific Studies, University of the South Pacific.

Spoonley, Paul. 2001. 'Transnational Pacific Communities: Transforming the Politics of Place and Identity'. In Tangata o Te Moana Nui: The Evolving Identities of Pacific Peoples in Aotearoa/New Zealand, edited by Cluny Macpherson, Paul Spoonley, and Melani Anae, 81-96. Palmerston North: Dunmore Press.

Sua'ali'i, Tamasailau. 2001. 'Samoans and Gender: Some Reflections on Male, Female and Fa'afafine Gender Identities'. In Tangata o Te Moana Nui: The Evolving Identities of Pacific Peoples in Aotearoa/New Zealand, edited by Cluny Macpherson, Paul Spoonley, and Melani Anae, 160-18o. Palmerston North: Dunmore Press.

Tamasese, Kiwi, Carmel Peteru, Charles Waldegrave, and Allister Bush. 2005. 'Ole Taeao Afua, The New Morning: A Qualitative Investigation into Samoan Perspectives on Mental Health and Culturally Appropriate Services'. Australian and New Zealand Journal of Psychiatry 39:300-309.

Tamasese, Kiwi, Tafaoimalo Loudeen Parsons, and Charles Waldegrave. 2014. 'Pacific Perspectives on Ageing in New Zealand'. Wellington: The Family Centre, Anglican Social Services.

Tate, Henare Arekatera. 2010. 'Towards Some Foundations of a Systematic Māori Theology: He tirohanga anganui ki ètahi kaupapa hōhonu mō te whakapono Māori. PhD thesis, Melbourne College of Divinity. 
Taule'ale'ausumai, F. 1997. 'Pastoral Care: A Samoan Perspective'. In Counselling Issues \& South Pacific Communities, edited by Philip Culbertson, 215-237. Auckland: Snedden \& Cervin Publishing.

Tiatia, Jemaima. 1998. Caught Between Cultures: A New Zealand-born Pacific Island Perspective. Auckland: Christian Research Association.

Tofaeono, Amaamalele. 200o. Eco-Theology: Aiga-the household of life: A Perspective from Living Myths and Traditions of Samoa. Neuendettelsau: Erlanger Verlag für Mission und Ökumene.

Tuagalu, Iuogafa. 2008. 'Heuristics of the Và'. AlterNative: An International Journal of Indigenous Peoples 4 (1):107-126.

Tui Atua, Tupua Tamasese Taisi Efi. 2014. 'Whispers and Vanities in Samoan Indigenous Religious Culture'. In Whispers and Vanities: Samoan Indigenous Knowledge and Religion, edited by Tamasailau M. Suaalii-Sauni, Maualaivao Albert Wendt, Vitolia Mo'a, Naomi Fuamatu, Upolu Luma Va'ai, Reina Whaitiri, and Stephen L. Filipo, 63-117. Wellington: Huia.

Vaka'uta, Nasili. 2015. 'Island-Marking Texts: Engaging the Bible in Oceania'. In Islands, Islanders, and the Bible RumInations, edited by Jione Havea, Margaret Aymer, and Steed Vernyl Davidson, 57-64. Atlanta, GA: SBL Press.

Van der Ryn, Fepuleai Micah. 2016. 'Which Way is Front? Spatial Orientation Complications in Contemporary Samoan Villages'. Structure \& Dynamics: eJournal of Anthropological \& Related Sciences 9 (1):114-135.

Wendt, Albert. 1999. 'Afterword: Tatauing the Post-Colonial Body'. In Inside out: Literature, Cultural Politics, and Identity in the Vew Pacific, edited by Vilsoni Hereniko and Rob Wilson, 399-412. Lanham, MD: Rowman \& Littlefield. 